РОЗДІЛ 2

ГЕРМАНСЬКІ МОВИ

UDC 811.111.81'42

DOI https://doi.org/10.32782/tps2663-4880/2021.18.15

\title{
PRAGMATIC PROPERTIES OF AUTHOR'S DIGRESSION IN ENGLISH LITERARY PROSE
}

\author{
ПРАГМАТИЧНІ ОСОБЛИВОСТІ АВТОРСЬКОГО ВІДСТУПУ \\ В АНГЛОМОВНИХ ХУДОЖНІХ ПРОЗОВИХ ТЕКСТАХ
}

\author{
Arkhipova I.M., \\ orcid.org/0000-0001-5536-2779 \\ Candidate of Philological Sciences, \\ Associate Professor at the Department of Germanic Philology \\ Horlivka Institute for Foreign Languages of Donbas State Pedagogical University
}

This article focuses on revealing syntactic and pragmatic properties of author's digression in English literary prose of the XIX-XX centuries.

Author's digression is determined as an autosemantic compositional unit of literary text, which ensures semantic relationship of different elements of the text, performs emotional and esthetic, phatic and cognitive functions, and is considered to be explicit means in defining the author's and reader's images.

The research was conducted in line with the latest achievements of text linguistics, aimed at identifying the communicative and pragmatic features of the text and the linguocognitive characteristics of the author's speech, which is realized in textual elements. As compositional units of the text, the author's digressions highlight the author's attitude to the events depicted in the work and determine the pragmatic influence on the addressee. The linguopragmatic approach made it possible to determine the pragmatic types of utterances that are part of the author's digressions (constatives, performatives, directives, quesitives).

It is proved that a significant number of constatives in the author's digressions testify to the author's image as a profoundly conscious linguistic personality. The addresser acts as a regulator of the formation of the reader's view, his behavior in a given situation, so the second position is occupied by directives. The addresser tries to evoke the speech act of the addressee and get the relevant information from the addressee to his question with the help of quesitives. However, such intention is not so often observed in the texts. And the last position in this rating is occupied by performatives. With such statements, the addresser encourages the addressee to take action, regulates interpersonal relationships. But since performatives are characterized by functioning in the context of direct communication, their presence in the analyzed author's digressions was not so frequent.

Key words: author's digression, literary text, addressee, addresser, constatives, performatives, directives, quesitives.

Стаття зосереджена на розкритті синтаксичних і прагматичних властивостей авторського відступу в англійській літературній прозі XIX-XX століть.

Авторський відступ розглядаємо як автосемантичну композиційно-смислову одиницю художнього тексту, що забезпечує смислову зв'язність тексту, виконує емотивно-естетичну, фатичну та когнітивну фуннкції й у такий спосіб виступає експліцитним засобом визначення образу автора і читача у тексті.

Дослідження проведено у руслі новітніх надбань лінгвістики тексту, спрямованої на виявлення комунікативнопрагматичних особливостей тексту і лінгвокогнітивної характеристики авторського мовлення, що реалізується у текстових внесеннях. Як композиційні одиниці тексту авторські відступи слугують висвітленню авторського ставлення до зображуваних у творі подій і визначенню прагматичного впливу на адресата. Лінгвопрагматичний підхід уможливив визначення прагматичних типів висловлень, котрі входять до складу авторських відступів (констативи, перформативи, директиви, квеситиви).

Доведено, що значна кількість констативів у складі авторських відступів свідчить про образ автора як глибоко усвідомлену мовну особистість. Адресант виступає регулятором формування думки читача, його поведінки в тій чи іншій ситуації, тому другу позицію займають директиви. Викликати мовленнєву дію адресата й отримати від адресата відповідну інформацію на своє запитання адресант намагається за допомогою квеситивів. Останню позицію в цьому рейтингу займають перформативи. Такими висловленнями адресант спонукає адресата до здійснення дій, регулює міжособистісні відносини, але, оскільки перформативам властиве функціонування у контексті прямого спілкування, наявність їх у складі аналізованих авторських відступів виявилася не такою частою.

Ключові слова: авторський відступ, художній текст, адресат, адресант, констатив, перформатив, директив, квеситив. 
Problem Setting. One of the priority areas oflinguisticresearchat thepresentstageofdevelopment of language science is the study of communicative and pragmatic aspects of the use of language, which involves the consideration of language in real contexts of functioning.

Highlighting the previous studies and referring to literature. A communicative act is traditionally defined as the interaction of sender and recipient [5]. According to G.V. Kolshanskyi, "the communicative aspect of language, focused on the study of the result - the effect of speech communication, can be called the pragmatics of language as its integral characteristic in terms of the interaction of communicators in communication" [4]. Thus, there is a new aspect of linguistic analysis of the literary text from identifying communicative intention. The researcher's task is to determine how and through what linguistic means (explicit or implicit) the communicative instruction of the text is realized and how the desired pragmatic effect can be achieved. In other words, linguistic research aims not only to study the semantic coherence of the text but also to describe the intention based on the author's intention. In the communicative-pragmatic key, the literary text we understand as a linguistic act between the author (addresser) and the reader (addressee). There are three levels in the speech act: locative (transmission of information, which is represented by phonetic, lexical-grammatical, and semantic structures), illocutionary and perlocutionary (realization of intentional influence on the addressee) [7].

Pragmatic interpretation of the author's digression is an urgent scientific problem taking into consideration that digressions are on the border of individual and social and reflect an essential aspect of the interaction of the individual linguistic personality of the author.

The research aims to systematize and classify the author's digressions in English prose from a comprehensive approach focused on identifying their linguistic and pragmatic properties. The object of the work is the author's digressions in English literary prose of the XIX-XX centuries.

The material. The material of the research was English literary prose of the XIX-XX centuries. The author's digression is considered as an autosemantic compositional unit of the literary text, which provides semantic coherence of the text, performs emotionalaesthetic, phatic, and cognitive functions, and thus acts as an explicit means of determining the author's and reader's images.

Findings and discussion. According to A. van Dijk, the addresser keeps in mind the idea of a particular context during creating the text. The scientist understands the context as the cognitive knowledge of a particular situation [3]. "Such a contextual model contains information about any social situation, it controls both style and content and, therefore, the idea of what information can or should be found in the situational model" [3, p. 170]. In this case, the context model controls the search in the memory of the relevant situation about what information should be transmitted in the text. The reader, in turn, reads the relevant information in the existing situational models in his memory and, thus, constructs semantic representations that lie in the deep structure of the text[3, p. 169].

Pragmatic features also characterize the attitude of the addressee to the text. "The addressee, as the plotline moves, believes and thinks that the "picture of the world" of the reproduced text is happening or has happened. And although the time, events, place of action, and behavior of the characters do not correspond to real-time, the addressee and the addresser understand the "picture" of the story as objective, sincerely believing in what is reproduced and read" [6]. The reader's attitude to this "picture of the world" shows his pragmatic decision; the reader may believe or disbelieve, empathize with the characters or be indifferent $[1 ; 2]$.

There are several classifications of illocutionary acts, the quantitative and qualitative composition of which is heterogeneous. J. Searle argues that there are at least twelve linguistically significant parameters by which illocutionary acts can be classified. The most significant of them, he considers the illocutionary goal, the direction of "adaptation" of the statement to the reality in question, and differences in the psychological state under which the illocutionary act is formed and occurs [11-13]. Based on these parameters, J. Searle identifies five types of illocutionary acts: representatives, directives, commissives, expressives, declarations [11].

In the study, we will follow the classification proposed by G.G. Pocheptsov [5]. The scientist identified the following types of pragmatic utterances: constative, promisive, menasive, performative, injunctive, requestive, and quesitive.

In the text fragment by G. Green's novel "The Quiet American" (2004) with the help of the author's digression, which includes constatives, the function of the emotional influence of the addresser on the point of view of the addressee is realized:

"I did not mean that", Pyle said. "When you are in love, you want to play the game, that is all." That is true, I thought, but not as he innocently means it. To be in love is to see yourself as someone else sees 
you; it is to be in love with falsified and exalted image of yourself. In love, we are incapable of honorthe courageous act is no more than playing a part to an audience of two. Perhaps I was no longer in love but I remembered... [8, p. 102].

In the above convergent autosemantic author's digression, the narrator reflects on the meaning of love and addresses to the addressee with complete confidence that his point of view is clear. At the syntactic level, implementing such a strategy is carried out by using complex affirmative sentences. Addressing to the reader is marked by using the pronoun You and its derivative form yourself, by a graphic pause before the final statement, which helps the reader to concentrate and achieve an illocutionary purpose. The syntactic convergence of the author's digression is based on syntactic chiasm (to be in love - the subject in the first part of the first statement, and the predicate in the second part of the first statement), as well as comparative constructions (as someone else sees you, no more than playing), emotionally affects the views of the recipient.

In the following example, the convergent author's digression functions as a constative:

Here lies the unreality of fiction. For men, as a rule, love is an episode that takes its place among the other affairs of the day, and the emphasis laid on it in novels gives it an importance that is untrue to life. There are few men to whom it is the most important thing globally, and they are not very interesting ones; even women, with whom the subject is of paramount interest, have a contempt for them. They are flattered and excited by them but have an uneasy feeling that they are poor creatures. But even during the brief intervals in which they are in love, men do other things which distract their minds; the trades by which they earn their living engaged their attention; they are absorbed in sport. For the most part, they keep their various activities in various compartments, and they can pursue one to the temporary exclusion of the other. They have a faculty of concentration on that which occupies them at the moment, and it irks them if one encroaches on the other. As lovers, the difference between men and women is that women can love all day long, but men only at times $[9, \mathrm{p} .162]$.

In this author's digression, the author intends to show the differences between men and women and their attitude to love. In the given example of the author's digression all sentences are constatives; therefore, the digression itself functions as a constative. In this example, the addresser describes one of the episodes in human life - the period of love. The author states that love is an episode for most men, the same as all the others in their everyday life (For men, as a rule, love is but an episode which takes its place among the other affairs of the day). He states that a woman loves all day long but a man - from time to time (the difference between men and women is that women can love all day long, but men only at the time).

The author's digressions do not always consist of statements of one pragmatic type. There are digressions characterized by a different structure, i.e., the digression consists of statements of different pragmatic types. The pragmatic orientation of the text can arise as an integral feature of the text set of sentences. Therefore, the pragmatic types of individual sentences in the text may differ from the pragmatic type of text as a whole [5].

Following G.G. Pocheptsov, we believe that the defining moment is the communicative intention of the text as a whole, and the basis for its definition may be the presence in it corresponding to this intention (pragmatic characteristics) statements (at least one) [5].

For example, in fragment from "The Moon and Sixpence" (1972) the author's digressionreflection contains statements that belong to different pragmatic types:

Strove sighed a little and was silent. His thoughts dwelt among pictures of what might have been, and the safety of the life he had refused filled him with longing. "The world is hard and cruel. We are here none knows why, and we go none knows whither. We must be very humble. We must see the beauty of quietness. We must go through life so inconspicuously that Fate does not notice us. And let us seek the love of simple, ignorant people. Their ignorance is better than all our knowledge. Let us be silent, content in our little corner, meek and gentle like them. That is the wisdom of life". To me, it was his broken spirit that expressed itself, and I rebelled against his [9, p. 125].

The author's digression begins with a constative (The world is hard and cruel), in which the conclusion is a result of the addresser's life experience. This statement is a simple sentence and, in compositional terms, serves as a starting point for further development of the author's reflection. In the second statement, which also acts as a constative (We are here none knows why, and we go none knows whither), the addresser complicates the syntactic construction with complex constructions, uses the connecting conjunction and, which has an emotional effect on the addressee. The perlocutionary effect of the action on the addressee's feelings is enhanced by the epiphora (none knows why none knows whither), where the main element is the negative pronoun none, 
which explicates the meaning of uncertainty. With the help of parallel anaphoric constructions in directive statements (We must be very humble; We must see the beauty of quietness; We must go through life so inconspicuously that Fate does not notice us), a communicative act is realized, in which the author motivates to take actions. Specific grammatical forms of requestives (Let us be silent, let us seek) in directive utterances aim to neutralize the unequal relationship between the addresser and the addressee. The expression of a call to joint activity in the form of imperative sentence testifies to the tolerance of the addresser, and the aphoristic sentence (That is the wisdom of life), which concludes in the author's digression, testifies to his awareness of life's affairs.

An example of the author's digression from the novel "The Razor's edge" (2004) by S. Maugham demonstrates the combination of different pragmatic types within one inclusion:

Has it occurred to you that transmigration is at once an explanation and justification of the evil of the world? (1) If the evils were suffered are the results of sins committed in our past lives we can bear them with resignation and hope that if in this one we strive towards virtue, our future lives will be less afflicted. (2) But it is easy enough to bear our own evils, all we need for that is a little manliness; what's intolerable is the evil, often so unmerited in appearance, that befalls others. (3) If you can persuade yourself that it is the inevitable result of the past, you may pity, you may do what you can to alleviate, and you should, but you have no cause to be indignant [10, p. 268].

This author's digression consists of inhomogeneous statements: (1) - directives (in the main part of the sentence), (2) - constatives, (3) - directives (in the main part of the sentence). In statements (1) and (3) the addresser appeals to the addressee, pointing to their equal position in the implementation of the action, the marker of which is the pronoun we (in the first statement) and you (in the third). The second statement is constative, summarizes the theme of suffering (But it is easy enough to bear our own evils, we all need for that is a little manliness). The addresser expresses the opinion that personal disagreements are easy to survive, it only takes a little courage. In this digression, the constative takes the central position because the pragmatic guideline of the digression lies in explanation to the addressee the fact that truly unbearable is the evil that seems undeserved, from which others suffer (What's intolerable is the evil, often so unmerited in appearance, that befalls others).
The following examples illustrate the wide range of pragmatically inhomogeneous statements that are part of the author's digression:

I used to listen to the monks repeating the Lord's Prayer; I wondered how they could continue to pray without misgiving to their heavenly father to give them their daily bread. (1) Do children beseech their earthly father to give them sustenance? (2) They expect him to do it, they neither feel nor need to feel gratitude to him for doing it, and we have only blamed for a man who brings children into a world that he can not or won't provide for [10, p. 257].

The underlined author's digression is an example of using non-homogeneous expressions: (1) - quesitive, (2) - constative. The quesitive has a structural feature of questionability. The primary function of the quesitive is to evoke the action of the addressee (speech actions only). The most crucial distinguishing feature of the quesitive should be considered as the connection of its use with the difference in information potential of the author of the quesitive and the addressee. By using a quesitive, its author points out the existence of such a difference and wants to remove this difference by obtaining the relevant information from the addressee. The quesitive focuses on the fact that the addressee lacks some information and creates, due to questioning, psychological tension, which is removed by answering [113]. The first statement in the interrogative form sets the theme of the whole digression: (Do children beseech their earthly father to give them sustenance?) The following statement contains a possible answer: (They neither fell nor need to feel gratitude to him for doing it.). The author's digression is a constative, where the addresser expresses a generalized opinion on this issue: (we have only blamed for a man who brings children into a world that he can not or will not provide for).

Let's analyze the example of the author's digression from the novel by E. Waugh "Decline and Fall' (1988):

(1) Why can not the creatures stay in one place? (2) Up and down, in and out, round and round! (3) Why can not they sit still and work? (4) Do dynamos require staircases? (5) Do monkeys require houses? (6) What an immature, self-destructive, antiquated mischief is, man! (7) How obscure and gross his prancing and chattering on his little stage of evolution! (8) How loathsome and beyond words boring all the thoughts and self-approval of his biological by-product! (9) This half-formed, illconditioned body! (10) This erratic, maladjusted mechanism of his soul: on one side the harmonious instincts and balanced responses of the animal, 
on the other the inflexible purpose of the engine, and between the man, equally alien from the being of Nature and the doing of the machine, the vile becoming! [14, p. 123-124].

The use of pragmatically inhomogeneous statements is clearly expressed in this author's digression: (1) - quesitive, (2) - constative, (3) quesitive, (4) - quesitive, (5) - quesitive, (6), (7), 8), (9), (10) - constatives. As in the previous example, the first statement sets the theme of the whole digression: Why can't the creatures stay in one place? The next four statements expand it; in this case, the quesitives sentences contain questions, the answers to which the addressee receives later. The sixth statement is a constative where the addresser summarizes human qualities and claims that man is an immature, harmful, outdated beginning: What an immature, self-destructive, antiquated mischief is the man! The following statements explain and specify this fact. The last statement summarizes all that has been said and informs the addressee of human nature's dual nature. On the one hand, the balanced behavior of the animal, on the other hand - the steadfast purposefulness of the machine: on the other the inflexible purpose of the engine, and between the man, equally alien from the being of Nature and the doing of the machine, the vile becoming! This author's digression acts as a constative because the pragmatic guideline of the digression is to explain to the addressee the author's point of view. The using of quesitives in the digression is used mainly to attract the addressee's attention to establish contact, i.e., with the phatic function.

Conclusions and Perspectives. A significant number of constatives in the author's digressions testify to the author's image as a profoundly conscious linguistic personality. The addresser acts as a regulator of the formation of the reader's view, his behavior in a given situation, so the second position is occupied by directives. The addresser tries to evoke the speech act of the addressee and get the relevant information from the addressee to his question with the help of quesitives. However, such intention is not so often observed in the texts. And the last position in this rating is occupied by performatives. With such statements, the addresser encourages the addressee to take action, regulates interpersonal relationships. But since performatives are characterized by functioning in the context of direct communication, their presence in the analyzed author's digressions was not so frequent.

Studies of the cognitive aspect of the author's digression in the different literary texts of English and American prose are promising.

\section{REFERENCES:}

1. Арутюнова Н.Д. Язык и мир человека. Москва : Языки русской культуры, 1999. 896 с.

2. Арутюнова Н.Д. Фактор адресата. Известия АН СССР. Сер. Лит. и яз. 1981. Т. 40. № 4. С. 356-357.

3. Дейк ван Т.А., Кинч В. Стратегии понимания связного текста. Новое в зарубежной лингвистике. Когнитивные аспекты языка. 1988. № XXIII. С. 153-211.

4. Колшанский Г.В. Коммуникативная функция и структура язика. Москва : Наука, 1984. 174 с.

5. Почепцов Г.Г. Прагматика текста. Коммуникативно-прагматические и семантические функции речевых единств : сборник научных трудов. Калинин : Калинин. гос. ун-т., 1980. С. 5-10.

6. Щербина Э.Ф. Текст художественного произведения, его синтактико-семантические и прагматические аспекты. Лингвистические единицы разных уровней в языке и речи. Краснодар : Изд-во Кубан. гос. ун-та, 1988. C. $145-151$.

7. Austin G. How to do Things with words. Oxford : Oxford University Press, 1962. $167 \mathrm{p}$.

8. Green G. The Quiet American. Москва : Менеджер, 2004. 176 p.

9. Maugham W.S. The Moon and Sixpence. Moscow : Progress Publishers, 1972. 250 p.

10. Maugham W.S. The Razor's edge. Москва : Менеджер, 2004. 320 p.

11. Searle J.R. A Classification of Illocutionary Acts. Language in Society, 1976, vol. 5. № 1. P. 1-23.

12. Searle J.R. A Taxonomy of Illocutionary Acts. Expression and Meaning. Studies in the Theory of Speech Acts. Cambridge : Cambridge University Press, 1979. P. 1-29.

13. Searle J.R. Speech Acts. An Essay in the Philosophy of Language. Cambridge: Cambridge University Press, 1969. $120 \mathrm{p}$.

14. Waugh E. Prose. Memoirs. Essays. Moscow : Progress Publishers, 1988. 445 p. 